\title{
Decreased spermatogenic and androgenic testicular functions in adult rats submitted to immobilization-induced stress from prepuberty
}

S.A. Almeida ${ }^{1}$, S.O. Petenusci², J.A. Anselmo-Franci², A.A.M. Rosa-e-Silva ${ }^{1}$ and T.L. Lamano-Carvalho
${ }^{1}$ Departamento de Fisiologia, Faculdade de Medicina de Ribeirão Preto, and ${ }^{2}$ Departamento de Morfologia, Estomatologia e Fisiologia, Faculdade de $O$ dontologia de Ribeirão Preto, Universidade de São Paulo, Ribeirão Preto, SP, Brasil

\section{Correspondence}

T.L. Lamano-Carvalho

Faculdade de $O$ dontologia de

Ribeirão Preto, USP

Av. Café, $s / n$

14040-904 Ribeirão Preto, SP

Brasil

Fax: + 55-16-633-0999

E-mail: tllc@forp.usp.br

Research supported by FAPESP

(No. 97/2498-1) and CNPq

(No. 520128/96-6). S.A. Almeida

is the recipient of a $\mathrm{CNPq}$

fellowship (No. 141513/95-0).

Received March 26, 1998

Accepted August 7, 1998

$\ldots \ldots \ldots \ldots \ldots \ldots$

\section{Abstract}

We investigated whether chronic stress applied from prepuberty to full sexual maturity interferes with spermatogenic and androgenic testicular functions. Male Wistar rats (40 days old) were immobilized $6 \mathrm{~h}$ a day for 60 days. Following immobilization, plasma concentrations of corticosterone and prolactin increased $135 \%$ and $48 \%$, respectively, while plasma luteinizing hormone and testosterone presented a significant decrease of $29 \%$ and $37 \%$, respectively. Plasma concentration

\section{Key words}

- Immobilization

- Spermatogenesis

- LH

- $\mathrm{FSH}$

- Testosterone

- Prolactin stress reduced the amount of mature spermatids in the testis by $16 \%$ and the spermatozoon concentration in the cauda epididymidis by $32 \%$. A $17 \%$ reduction in weight and a $42 \%$ decrease in DNA content were observed in the seminal vesicle of immobilized rats but not in its fructose content. The growth and secretory activity of the ventral prostate were not altered by chronic stress.

\section{Introduction}

Although short- or long-term immobilization is stressful to laboratory animals, the magnitude of the response depends on the intensity and duration of the stimulus (1-11). Experiments are in progress in our laboratory using a model of aversive stimulation $6 \mathrm{~h}$ of daily immobilization - to investigate the effects of stress on the onset of puberty in male rats. When applied from prepuberty (40 days of age) to early puberty (55 days of age) the stressful stimuli significantly de- creased plasma luteinizing hormone (LH) concentration but caused a marked increase in plasma testosterone; a lower extent of testicular maturation was also found in pubertal stressed animals (Almeida SA, Petenusci SO, Anselmo-Franci JA, Rosa e Silva AAM and Lamano Carvalho TL, unpublished results).

The purpose of the present study was to investigate the progression of these reproductive disorders by examining the effects of stress-induced immobilization, applied from prepuberty, on spermatid production, 
spermatozoon concentration in the cauda epididymidis and on the accessory sex glands of adult rats.

\section{Material and Methods}

Male Wistar rats were submitted to immobilization from prepuberty (40 days of age) to full sexual maturity (100 days of age). The phases of sexual development were established according to Zanato et al. (12). The animals were housed four to a cage in plastic boxes $(40 \times 32 \times 17 \mathrm{~cm})$ under controlled environmental conditions (12-h light period starting at 8:00 h, temperature $23 \pm$ $2^{\circ} \mathrm{C}$ ). Laboratory chow and tap water were given ad libitum.

The animals $(\mathrm{N}=8)$ were immobilized inside plastic tubes dimensioned to produce stress without promoting pain $(4.5 \mathrm{~cm}$ in diameter $x 15.5 \mathrm{~cm}$ long up to 55 days of age; $5.0 \mathrm{~cm}$ in diameter $\mathrm{x} 25.5 \mathrm{~cm}$ long up to 100 days) for $6 \mathrm{~h}$ a day over a period of 60 days. Control rats $(\mathrm{N}=8)$ were left undisturbed in their cages. Undesirable stress was avoided as much as possible by gentle handling and

Table 1 - Plasma hormone concentrations of chronically immobilized adult rats.

Rats were immobilized for $6 \mathrm{~h} /$ day from day 40 to 100 of life. Data were obtained by radioimmunoassay and are reported as means \pm SEM for 8 rats in each group. $* \mathrm{P}<0.05$ compared to control (Mann-Whitney test).

\begin{tabular}{lcc}
\hline & \multicolumn{2}{c}{ Groups } \\
\cline { 2 - 3 } & Control & Immobilized \\
\hline $\begin{array}{l}\text { Corticosterone } \\
\text { (ng/ml) }\end{array}$ & $98.8 \pm 19.4$ & $231.9 \pm 43.9^{*}$ \\
$\begin{array}{l}\text { Prolactin } \\
\text { (ng/ml) }\end{array}$ & $19.0 \pm 2.3$ & $28.1 \pm 4.0^{*}$ \\
$\begin{array}{l}\text { FSH } \\
\text { (ng/ml) }\end{array}$ & $14.1 \pm 0.8$ & $12.4 \pm 0.3$ \\
$\begin{array}{l}\text { LH } \\
\text { (ng/ml) }\end{array}$ & $5.19 \pm 1.93$ & $3.70 \pm 0.40^{*}$ \\
$\begin{array}{l}\text { Testosterone } \\
\text { (ng/ml) }\end{array}$ & $2.92 \pm 0.28$ & $1.83 \pm 0.30^{*}$ \\
\hline
\end{tabular}

noiselessness throughout the experiment.

Stressed and control rats were killed by decapitation in the morning after the last stressing session. Trunk blood was collected into heparinized tubes and plasma was separated by centrifugation and stored at $-20^{\circ} \mathrm{C}$ for hormone determinations. Testosterone $(\mathrm{T})$, prolactin $(\mathrm{Prl}), \mathrm{LH}$, and follicle-stimulating hormone (FSH) were measured by double-antibody radioimmunoassay as described by Zanato et al. (12). A commercial kit (Coat-A-Count Rat Corticosterone, DPC - Diagnostic Products Corporation, Los Angeles, CA) was used to measure plasma corticosterone.

The seminal vesicle and ventral prostate were removed, weighed and stored at $-20^{\circ} \mathrm{C}$ for colorimetric measurements of DNA and fructose (13). The sperm suspension was collected from the cauda epididymidis for evaluation of spermatozoon concentration, as described by Kempinas and Lamano Carvalho (14).

The testes were removed, weighed and immersed in Alfac fixing solution (85\% ethanol $80^{\circ}, 10 \%$ formaldehyde and $5 \%$ glacial acetic acid) for $24 \mathrm{~h}$. Seven- $\mu \mathrm{m}$ thick equatorial paraffin sections were stained with hematoxylin and eosin for histological and histometric analysis. Spermatid production was estimated by the amount of spermatids in the maturation phase (stages 15 to 18 of spermiogenesis, identified according to Ref. $15)$ counted in 10 seminiferous tubule crosssections per animal.

The results were analyzed statistically by the non-parametric Mann-Whitney test.

\section{Results}

Sixty days of immobilization markedly increased plasma corticosterone (135\%) and Prl (48\%) concentrations. Plasma LH and T decreased by $29 \%$ and $37 \%$, respectively, following chronic stress, while no significant change was observed in plasma FSH (Table 1). 
No change was observed in the testicular weight $(1.77 \pm 0.03 \mathrm{~g}$ in control and $1.69 \pm$ $0.05 \mathrm{~g}$ in immobilized rats) or in the gross histological features. However, a significant decrease in spermatid production was demonstrable by histometric evaluation, which revealed a $16 \%$ decline in the amount of maturing spermatids per seminiferous tubule cross-section. A $32 \%$ decrease in the concentration of spermatozoa stored in the cauda epididymidis was also observed in stressed rats (Figure 1).

Immobilization caused a significant reduction in seminal vesicle weight (17\%) and DNA content $(42 \%)$ but not in in its quantity of fructose. Ventral prostate growth and secretory activity were not altered (Table 2).

\section{Discussion}

Stress caused by chronic immobilization was confirmed by a significant rise in plasma corticosterone. Literature data have shown that frequent stimulation with a low-intensity stressor often leads to habituation of the hypothalamic-pituitary-adrenal axis, while lower frequency and/or high-intensity stimuli can promote an exaggerated response (16). A recent review (17) summarizes the role of the hippocampus in the control of a variety of vegetative functions, such as ACTH secretion, and provides evidence that repeated restraint stress can promote hippocampal atrophy. Considering the inhibitory role of the hippocampus in glucocorticoid synthesis, stress-induced dendritic atrophy may have contributed to high corticosterone levels following prolonged immobilization.

Plasma Prl is also expected to increase in response to stress $(18,19)$, but the response is usually of short duration because of the suppressive effect of the concomitant increase in adrenal glucocorticoids (18). In the present study, however, Prl remained elevated above control levels even $24 \mathrm{~h}$ after the last episode of repeated exposures to the stressor.
Our results support literature data showing no significant change in plasma FSH (7) and a decrease in plasma $\mathrm{LH}(7,9,10)$ after chronic immobilization of male rats. The stress-induced decrease in LH has been attributed to inhibition of gonadotropin releasing hormone $(\mathrm{GnRH})$ secretion (10).

In the present study, immobilization of male rats from prepuberty to sexual maturity caused a significant decrease in $\mathrm{T}$ secretion. The inhibitory effect of chronic immobilization on plasma $T$ has been a common finding in adult rats $(5-7,10,11)$ attributed to reduced LH concentration $(7,20)$. The precise mechanism of the inhibitory effect of prolonged stress on plasma $T$, however, is not

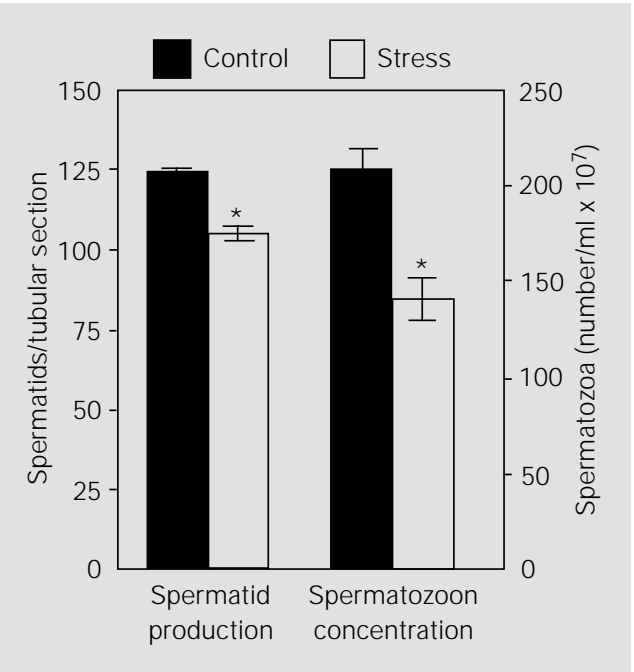

Figure 1 - Amount of spermatids (stages 15 to 18 of spermiogenesis) counted in 10 seminiferous tubular sections per animal (left) and concentration of spermatozoa in the cauda epididymidis (right), in chronically immobilized adult rats. Rats were immobilized $6 \mathrm{~h} /$ day from day 40 to 100 of life. Data are reported as mean \pm SEM for 8 rats in each group. $* \mathrm{P}<0.05$ compared to control (Mann-Whitney test).
Table 2 - Effect of immobilization on rat seminal vesicle and ventral prostate weight, and DNA and fructose content.

Rats were immobilized $6 \mathrm{~h}$ /day from day 40 to 100 of life. Data are reported as means \pm SEM for 8 rats in each group. $* \mathrm{P}<0.05$ compared to control (Mann-Whitney test).

\begin{tabular}{lccc} 
Group & $\begin{array}{c}\text { Weight } \\
(\mathrm{g})\end{array}$ & $\begin{array}{c}\text { DNA } \\
(\mathrm{mg})\end{array}$ & $\begin{array}{c}\text { Fructose } \\
(\mathrm{mg})\end{array}$ \\
\hline $\begin{array}{l}\text { Seminal vesicle } \\
\text { Control }\end{array}$ & $0.63 \pm 0.03$ & $0.33 \pm 0.03$ & $0.12 \pm 0.01$ \\
Immobilized & $0.52 \pm 0.04^{*}$ & $0.19 \pm 0.01^{*}$ & $0.11 \pm 0.01$ \\
& & & \\
Ventral prostate & & & \\
Control & $0.35 \pm 0.03$ & $0.14 \pm 0.01$ & $0.26 \pm 0.03$ \\
Immobilized & $0.34 \pm 0.02$ & $0.16 \pm 0.02$ & $0.27 \pm 0.03$
\end{tabular}


fully understood since the changes in androgenic response are not always associated with altered LH levels $(8,11,21)$. It was suggested that restraint stress may induce Leydig cell hyposensitivity to gonadotropin leading to a blockade of $\mathrm{T}$ biosynthesis at normal $\mathrm{LH}$ levels (21). More recent data have shown that increased glucocorticoids may act via glucocorticoid receptors on Leydig cells, thus suppressing the testicular response to gonadotropins (11). The proopiomelanocortin (POMC)-derived peptides may also play an autocrine/paracrine role in mediating the stress-induced decline in testicular steroidogenesis (8).

In contrast to the considerations discussed above, studies under way in our laboratory have shown an increase in $\mathrm{T}$ concentration in early pubertal rats submitted to chronic immobilization from prepuberty (Almeida SA, Petenusci SO, Anselmo-Franci JA, Rosa e Silva AAM and Lamano Carvalho TL, unpublished results), indicating that the stressful stimulus probably acts in a different way on the gonadal axis during distinct phases of sexual development. Sympathetic innervation seems to modulate androgen biosynthesis, particularly at prepuberty and early puberty. Previous studies from our laboratory dealing with the effects of chemical sympathectomy showed decreased steroidogenesis in prepubertal and early pubertal, but not in adult rats, at normal LH levels, and suggested that adrenergic stimulation plays a pivotal role in testicular steroidogenesis around the onset of puberty (22-24). If so, and since immobilization induces a significant rise in plasma epinephrine and norepinephrine levels (6), a sympathetic overstimulation might explain the increased $\mathrm{T}$ levels observed in pubertal stressed rats.

No change was observed in testicular weight or gross histological features after immobilization from prepuberty to sexual maturity; however, a significant decrease in both the production of maturing spermatids and concentration of spermatozoa in the cauda epididymidis was observed. The decreased androgenic status of stressed rats may be responsible, at least in part, for depressing spermatogenesis, since the stimulatory action of both FSH and T is needed to initiate and maintain the process (15). In addition to the hormonal control, local regulatory interactions occur between all testicular cell types (interstitial, peritubular myoid, germ and Sertoli cells) and these cell-cell communications, involving growth factors and POMC peptides, mediate the cell growth and differentiation required for the initiation and maintenance of spermatogenesis (25). The stressful stimulus may have also interfered with elements of this elaborate paracrine control, impairing the spermatogenic process.

Although chronic immobilization did not disturb prostate growth or secretory activity, the seminal vesicle became atrophied. The atrophic seminal vesicle of stressed rats might be a consequence of decreased $\mathrm{T}$ secretion, in addition to high Prl levels, since the growth and secretory activity of male accessory glands are under the main control of testicular androgens and $\operatorname{Prl}(26,27)$. There are, however, clear differences between the glandular response to androgens in distinct phases of sexual development: the prostate of peripubertal rats seems to be particularly responsive to testosterone when compared to younger or sexually mature animals, while the seminal vesicles showed decreasing responsiveness with increasing ages (28). Prl acts both independently and in synergy with $\mathrm{T}$ by intensifying the growth-promoting influence of androgens. However, while a normal circulating Prl level is essential for male reproductive functions, high levels produce adverse effects including glandular atrophy $(26,29)$.

In conclusion, immobilization-induced stress applied from prepuberty decreased spermatid production and spermatozoon 
concentration in the cauda epididymidis of adult rats. In contrast to the findings in pubertal rats (Almeida SA, Petenusci SO, Anselmo-Franci JA, Rosa e Silva AAM and Lamano Carvalho TL, unpublished data), however, $\mathrm{T}$ secretion decreased in sexually mature stressed animals. Thus, besides the intensity and duration of the stressful stimulus, the phase of sexual development should also be taken into ac- count in studies of the reproductive responses to stress.

\section{Acknowledgments}

The authors thank Dr. C.R. Franci for providing the facilities for hormone measurements, and Sonia A.Z. Baptista, Mauro F. Silva, Antonio de Campos and Edna A.S. Moraes for technical assistance.

\section{References}

1. Zemjanis R, Gondos B, Adey WR \& Cockett ATK (1970). Testicular degeneration in Macaca nemestrina induced by immobilisation. Fertility and Sterility, 21: 335-340.

2. Cockett ATK, Elbadawi A, Zemjanis R \& Adey WR (1970). The effects of immobilisation on spermatogenesis in subhuman primates. Fertility and Sterility, 21: 610614.

3. Cockett ATK, Zemjanis R, Elbadawi A \& Adey WR (1971). Male infertility: histochemical changes in the subhuman primate testis after prolonged immobilisation. Fertility and Sterility, 22: 565-572.

4. Meitner ER (1976). Einfluss der Immobilisation auf die Spermiogenese. Acta Anatomica, 95: 300-308.

5. Charpenet $G$, Taché $Y$, Forest MG, Haour F, Saez J M, Bernier M, Ducharme J R \& Collu R (1981). Effects of chronic intermittent immobilisation stress on rat testicular androgenic function. Endocrinology, 109: 1254-1258.

6. Collu R, Gibb W \& Ducharme J R (1984). Role of catecholamines in the inhibitory effect of immobilisation stress on testosterone secretion in rats. Biology of Reproduction, 30: 416-422.

7. Demura R, Suzuki T, Nakamura S, Komatsu H, Odagiri E \& Demura H (1989). Effect of immobilisation stress on testosterone and inhibin in male rats. J ournal of Andrology, 10: 210-213.

8. Mann DR \& Orr TE (1990). Effect of restraint stress on gonadal proopiomelanocortin peptides and the pituitary-testicular axis in rats. Life Sciences, 46: 1602-1609.

9. López-Calderón A, González-Quijano MI, Tresguerres J AF \& Ariznavarreta C (1990). Role of LHRH in the gonadotropin response to restraint stress in intact male rats. J ournal of Endocrinology, 124: 241246.

10. López-Calderón A, Ariznavarreta C, González-Quijano MI, Tresguerres J AF \& Calderón MD (1991). Stress induced changes in testis function. J ournal of Steroid Biochemistry and Molecular Biology, 40: 473-479.

11. Orr TE \& Mann DR (1992). Role of glucocorticoids in the stress-induced suppression of testicular steroidogenesis in adult male rats. Hormones and Behavior, 26: 350-363.

12. Zanato VF, Martins MP, Anselmo-Franci J AA, Petenusci SO \& Lamano Carvalho TL (1994). Sexual development of male Wistar rats. Brazilian J ournal of Medical and Biological Research, 27: 1273-1280.

13. Kempinas WG, Lamano Carvalho TL, Petenusci SO, Favaretto ALV, Lopes R \& Azoubel R (1988). Functional disturbance of rat sexual accessory glands in an early phase of lead intoxication. Gegenbaurs Morphologisches J ahrbuch, 134: 791-798.

14. Kempinas WG \& Lamano Carvalho TL (1988). A method for estimating the concentration of spermatozoa in the rat cauda epididymidis. Laboratory Animals, 22: 154-156.

15. Steinberger E \& Steinberger A (1975). Spermatogenic function of the testis. In: Greep RO \& Astwood EB (Editors), Handbook of Physiology. Vol. 5. Williams \& Wilkins, Baltimore, 1-19.

16. Pitman DL, Ottenweller JE \& Natelson BH (1990). Effect of stressor intensity on habituation and sensitization of glucocorticoid response in rats. Behavioral Neuroscience, 104: 28-36.

17. McEwen BS \& Magarinos AM (1997). Stress effects on morphology and function of the hippocampus. Annals of the
New York Academy of Sciences, 821 : 271-284.

18. Gala RR (1990). The physiology and mechanisms of the stress-induced changes in prolactin secretion in the rat. Life Sciences, 46: 1407-1420.

19. Nonaka KO, Midlej M, Cobas C, Ramalho MJ , Fregoneze J B, Machado A, AntunesRodrigues J \& Castro e Silva E (1991). Effects of central epinephrine synthesis inhibition on stress-induced prolactin secretion in male rats. Brazilian J ournal of Medical and Biological Research, 24: 1071-1079.

20. Sapolsky RM (1985). Stress-induced suppression of testicular function in the wild baboon: role of glucocorticoids. Endocrinology, 116: 2273-2278.

21. Charpenet $G$, Taché $Y$, Bernier $M$, Ducharme JR \& Collu R (1982). Stressinduced testicular hyposensitivity to gonadotropins in rats. Role of the pituitary gland. Biology of Reproduction, 27: 616623.

22. Lamano Carvalho TL, Guimarães MA, Kempinas WG, Petenusci SO \& Rosa e Silva AAM (1996). Effects of guanethidine-induced sympathectomy on the spermatogenic and steroidogenic testicular functions of prepubertal to mature rats. Andrologia, 28: 117-122.

23. Kempinas WG, Petenusci SO, Rosa e Silva AAM, Favaretto ALV \& Lamano Carvalho TL (1995). The hypophyseal-testicular axis and sex accessory glands following chemical sympathectomy with guanethidine of pre-pubertal to mature rats. Andrologia, 27: 121-125.

24. Rosa e Silva AAM, Guimarães MA, Lamano Carvalho TL \& Kempinas WG (1995). Chemical sympathectomy blocks androgen biosynthesis during prepuberty. 
Brazilian J ournal of Medical and Biological Research, 28: 1109-1112.

25. Skinner MK, Norton J N, Mullaney BP, Rosselli $M$, Whaley PD \& Anthony CT (1991). Cell-cell interactions and the regulation of testis function. In: Robaire B (Editor), The Male Germ Cell: Spermatogonium to Fertilization. Annals of the New York Academy of Sciences, 637: 354-363.

26. Mann T \& Lutwak-Mann C (1981). Secre- tory function of the prostate, semina vesicle, Cowper's gland and other accessory organs of reproduction. In: Mann T \& Lutwak-Mann C (Editors), Male Reproductive Function and Semen. Springer-Verlag, New York, 171-193.

27. Coffey DS (1988). Androgen action and the sex accessory tissues. In: Knobil E \& Neill LJ (Editors), The Physiology of Reproduction. Raven Press, New York, 1081-
1119.

28. Odell WD (1990). Sexual maturation in the rat. In: Gumbach MM, Sizonenko PC $\&$ Aubert ML (Editors), Control of the Onset of Puberty. Williams \& Wilkins, London, 183-210.

29. Bartke $A$ (1980). Role of prolactin in reproduction in male mammals. Federation Proceedings, 39: 2577-2581. 